\title{
Evaluating Ethiopia's Agricultural Export Potential: Empirical Evidence Using Gravity Model
}

\author{
Amare Alemaye Mersha \\ University of Pavia, PO box 27100, Italy. \\ E-mail: ame.econ91@gmail.com/amarealemaye.mersha01@universitadipavia.it
}

\begin{abstract}
Given Ethiopia's export revenue is mainly from agricultural primary products, this study attempted to estimate the major determinants of Ethiopia's agricultural export over the study period (1995-2015) using a dynamic gravity model. The empirical results are in favor of the model as it is likely to produce consistent results where the lagged agricultural export has a positive and significant effect on current agricultural export flows. Home country's population and trade openness are found to have a positive impact on agricultural export while importing country's population, distance and home country's contract-intensive money variables are found to be significant in affecting Ethiopia's agricultural export negatively. Furthermore, European countries including Israel, Switzerland, Greece, Norway, Finland, Sweden, Romania and Austria remained to be the dominant future potential destinations. Thus, export promotion towards these economies must be prioritized through bilateral trade agreement arrangements and reduction in public sector bottlenecks to exporters.
\end{abstract}

Keywords: Ethiopia; Dynamic Gravity Model; Agricultural Export Potential; System GMM Estimator.

\section{Introduction}

Ethiopia has joined the list of the fastest growing economies in the world and the country is the second most populous country in Africa with a population of around 97 million (WB, 2015). Ethiopia's economy is highly dependent on agriculture by which the sector contributes about 46.3 percent to the total growth in the country, 60 percent to export and 80 percent to the total employment (UNDP, 2015). In recent years, however, the service sector is taking the lead in terms of growth contribution though there is a valid skepticism that low income countries are growing without transforming their economy and hence they are experiencing premature de-industrialization. Ghani and O'Connell (2014) synthesized that a highly service based developing economy without the necessary economic transformation, could potentially struggle to have a sustainable growth path.

Though the role of foreign trade to Ethiopia's economy is very significant (trade accounts for about 25-50 percent of its Gross Domestic Product (GDP) by for the period 1995-2015), exports of the country are not diversified (see Figure 1). More importantly, the export side is dominated by few products like coffee, oil-seeds, leather and leather products, pulses, meat and meat products, fruits and vegetables, live animals, chat, gold, flower and electricity (ERCA, 2015, NBE, 2015). 


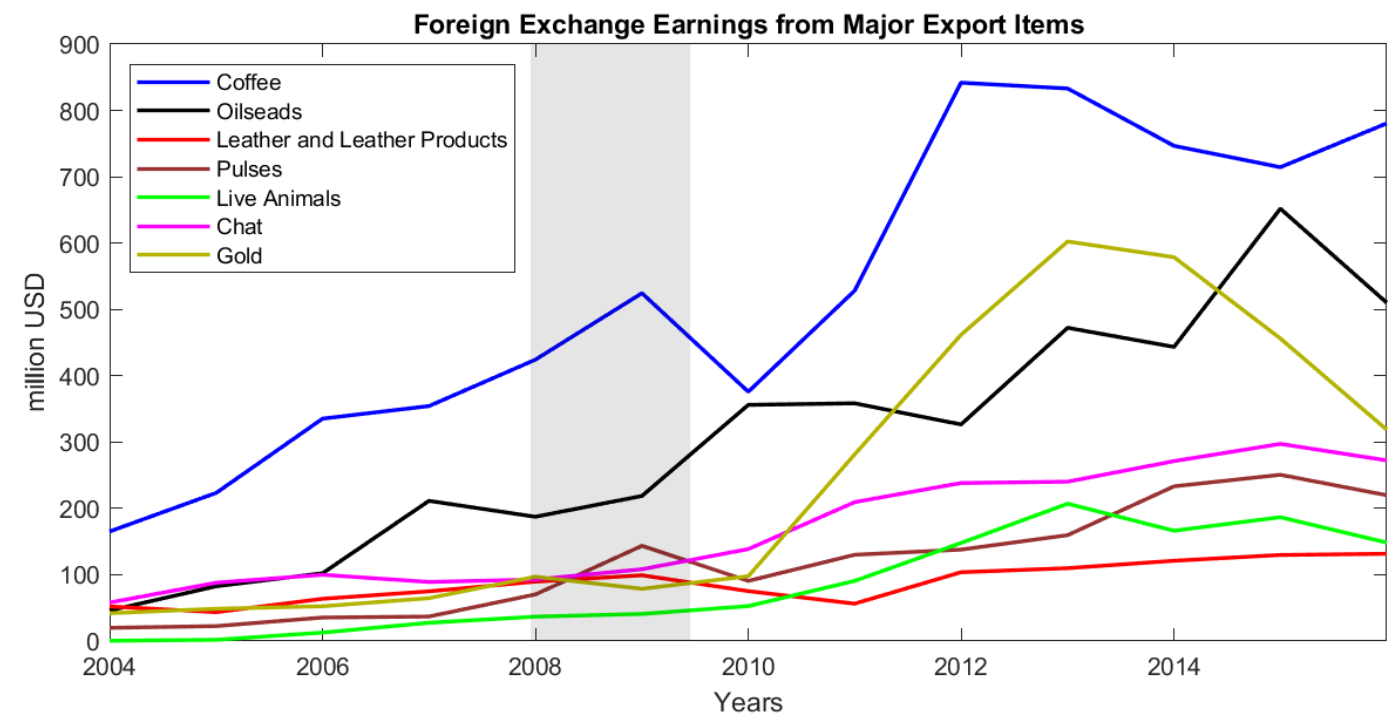

Figure 1: Ethiopia's Foreign Exchange Earnings from Major Export Items

Coffee and oil-seeds alone contributed more than half of the total earnings in the years between 2012 and 2015. From this trend, one can easily observe that the export trade is highly dependent on a limited variety of agricultural commodities though there are slight improvements in the degree of diversification as some other products like flower, live animals and pulses become significant export items recently (ERCA, 2014).

In general, the fact that Ethiopia's export revenue is highly dependent on agricultural export earning (see Figure 2) makes the sector more attractive to stakeholders involved in international trade and related policy makings.

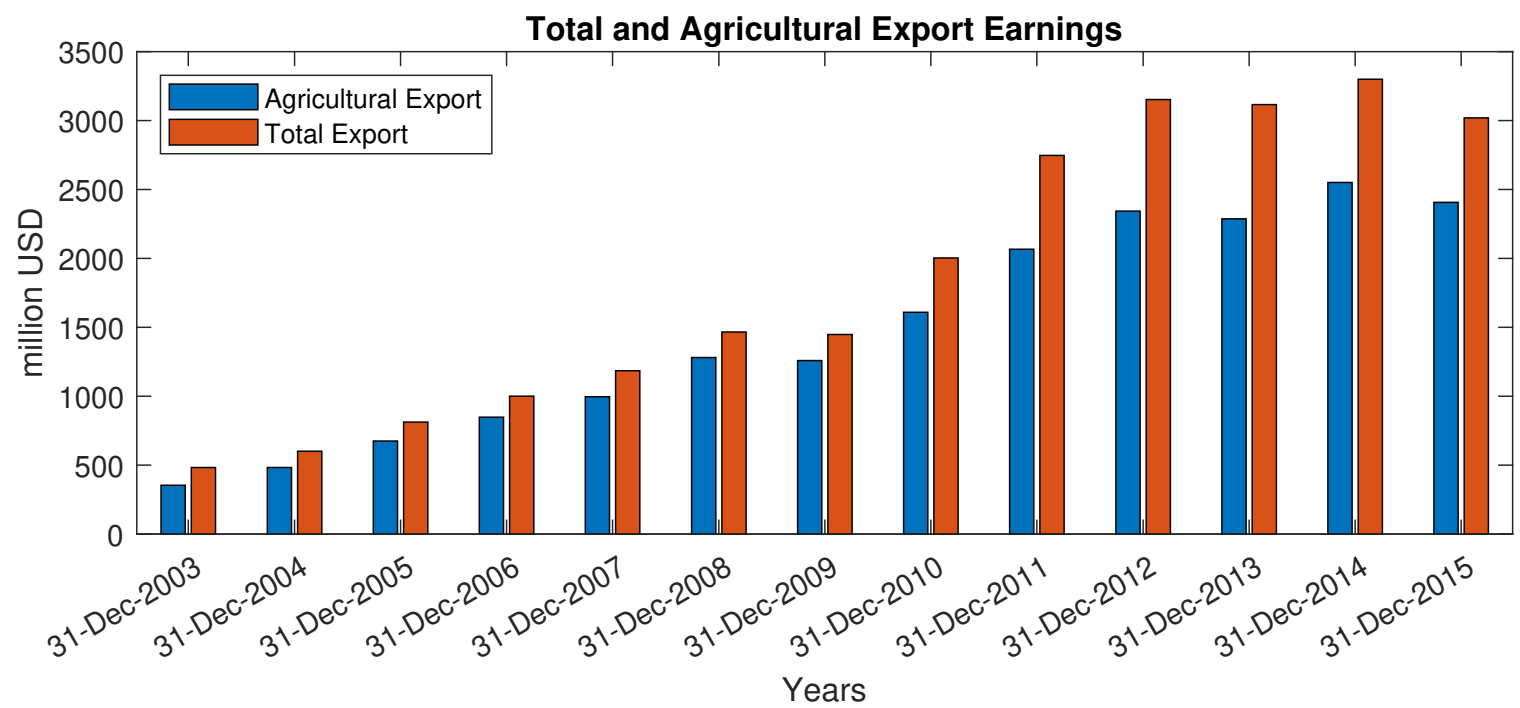

Figure 2: Agricultural Export Earnings Vs Total Export Earnings 
Notwithstanding the role of agriculture to the country's export earnings, the export performance of the sector itself, however, has been noticed to be poor (see Figure 3). Agricultural export intensity ${ }^{1}$ has been below 10 percent before 2009 which shows the country's poor involvement in the agricultural export trade implying that the large mass agricultural production in the country is not commercialized enough to the international market. However, it is also important to note that progresses has been registered during the first Growth and Transformation Plan² (GTP I).

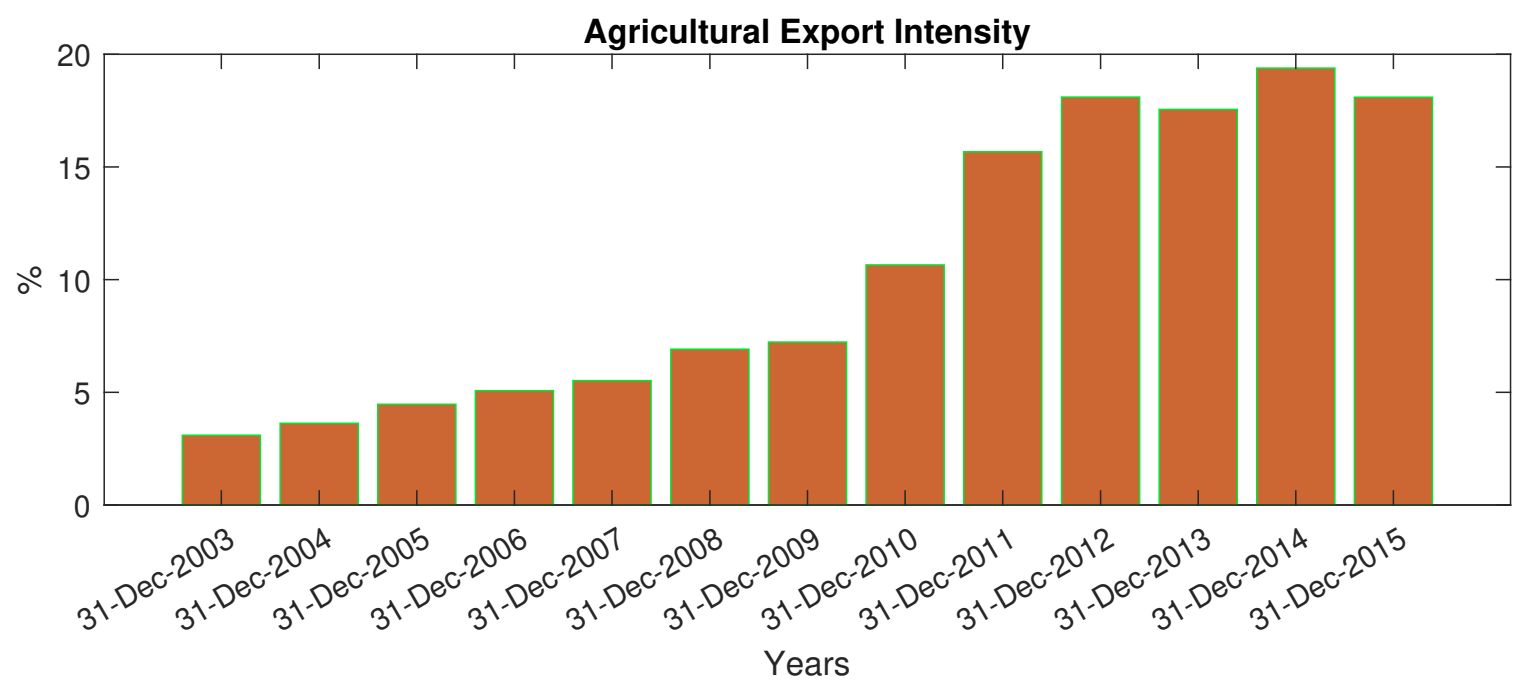

Figure 3: Agricultural Export Earnings Vs Total Export Earnings

Since agriculture is a very significant contributor of the country's export, exploring a way to boost its export competitiveness and maximize the gains would no longer be questionable. This invites to undertake an empirical investigation with a particular target to explain the determinants of Ethiopia's agricultural export and explore its potential.

As far as agricultural export trend of Ethiopia is concerned, the growth over time indicates that there were erratic changes to the country's total agricultural export. This is obvious that, among other things, the agricultural sector in the country is highly rain dependent. More specifically, the period from 1995-2004 has been known for a more or less steady growth of agricultural export. The period after 2004 till the period where the First Growth and Transformation Plan (GTP I) has been commenced in 2010, however, reflects that agricultural export of Ethiopia has been growing rapidly.

Despite the unanimous acceptance of the fact that international trade plays a significant role to nation's growth and development, there are different arguments in explaining the determinants of international trade and specialization.

Cognizant this fact, several previous studies attempted to examine the determinants of international trade of nations with their trading partners (see Antonucci and Manzocchi

\footnotetext{
${ }^{1}$ Agricultural Export Intensity refers to total agricultural export earnings divided by the total agricultural output and it is the most widely used measure of export performance for sectors (Reis and Forte, 2016, Sousa, 2004, Udah et al., 2015)

${ }^{2}$ GTP I (2010/11-2014/15) is a planning initiative by the government of Ethiopia with the objective to maintain the double digit real GDP growth rate of 11 percent, attain the Millennium Development Goals, to expand access and quality of health and education services, ensuring macroeconomic stability and stable democratic and developmental state (FDRE GTP II, 2016).
} 
(2005), Batra (2006), Hatab et al. (2010), Koo (2003), Kristjánsdóttir (2005), Simwaka (2006), Thapa (2012) and Nam (2004a)). These studies applied gravity model of trade for different nations and commonly identified that the volume of trade between pairs of countries is a positive function of the GDP of the two countries, similar membership to regional integration agreement, exchange rate, partner countries total import demand and the trade openness of the partner's economy, and negative function of the distance between them which is taken as a proxy for transportation and transaction costs. However, the results also indicated ambiguous sign of some economic variables like population and GDP per capita.

Similar studies with a gravity model approach in Ethiopia by Tedla (2011) and Kassa (2013) found that GDP per capita of both exporting and importing countries found to have positive and significant impact on Ethiopia's bilateral exports whereas, distance between countries negatively affect their bilateral trade. Rahman (2010), however, indicated that an increase in home country's GDP per capita has adverse effect on Egyptian agricultural export.

This particular study attempted to resolve the inconclusiveness nature of other studies regarding the impact of population. Earlier studies were also not comprehensive as they paid less emphasis to the possible impact of financial development and economic agents access to financial institutions on bilateral trade flows. On the top of that, there was no attempt or little attempt has been made to figure out the determinants of Ethiopia's bilateral trade with the rest of the world with a particular focus on agricultural products though the sector takes the lion share (60 percent) of the country's total export according to WB (2015).

Empirical contributions by Bekele (2011), Kassa (2013) and Gebrehiwot and Gebru (2015) attempted to figure out the major potential determinants of Ethiopia's bilateral trade with an emphasis either on total trade flows or total export flows and few agricultural product items using the gravity model approach. However, it is evident that developing countries in general and Ethiopia in particular exports mainly agricultural primary products implying the importance of understanding the major determinants and potentials of the country's bilateral trade by taking aggregate agricultural export items into consideration. Owing to this fact, this study attempted to identify the determinants of Ethiopia's agricultural export flow to its major trading partner countries using dynamic gravity model and evaluate the existing untapped or exploited agricultural export potential ${ }^{3}$ of the country with its major trading partners.

More importantly, this study addressed the main research agenda by answering the following research questions:

- Can the augmented gravity model of trade explain the agricultural export flows of Ethiopia with the major trading partner countries?

- What factors are responsible to explain the agricultural export flows of Ethiopia with the major importing partner countries?

- Did Ethiopia fully exploit its agricultural export potential with the major trading partner countries?

Considering the fact (see NBE (2015)) that the export destiny of Ethiopia is dominated by Asian (38.4 percent), European (33.6 percent), African (20.2 percent) and North Amer-

\footnotetext{
${ }^{3}$ Trade potential is broadly defined as the maximum possible trade that can be achieved within the context of frictionless trade, given the current level of trade, transport and institutional set up (Kalirajan, 1999, Kalirajan and Findlay, 2005)
} 
ican (7 percent) countries, this study has been confined to agricultural exports of Ethiopia to European, Asian, African and North American countries over the period 1995 - 2015.

\section{Literature Review}

\subsection{Conceptual Framework}

The term agriculture is broadly defined as cultivation of land. More specifically, it is the science and art of producing crops and livestock for economic purposes and from the natural resources of the earth (Chandrasekaran et al., 2010). In line with this, agriculture as an economic activity includes horticulture, fruit growing, seed growing, dairy farming and livestock breeding and keeping, the use of land as grazing land, meadow land, osier land, market gardens and nursery grounds, and the use of land for woodlands where that use ancillary to the farming of land for Agricultural purposes (Chandrasekaran et al., 2010, Smith, 2014).

The Ethiopian Ministry of Agriculture and Natural Resources (MoANR) as well treats agriculture as a biological production process, which depends on the growth and development of selected plants and animals within the local environment. More specifically, the records from Ethiopian Revenue and Customs Authority indicates that cereal and crop productions, animal and animal genetic materials (livestock products), horticulture, chat, fruits and vegetables, oil seeds and pulses and coffee and tea are the major marketable agricultural products in the country. On the basis of this understanding, this study defines agriculture in the above context and considers the aforementioned agricultural products as the major export items of Ethiopia eligible to our study despite the fact that mineral, power/electricity and some manufactured products are still registered as exportable items.

\subsection{Gravity Model of Trade and its Application}

The issue of why nations trade among themselves and what really determines the trading transactions between nations has been a fundamental question in the area of international trade and relations (Gandolfo, 1998).

Although there is no single trade theory that can alone describe the pattern of international trade, the current well known and acceptable modern trade theories were developed through evolution of ideas in the past. Among the different international trade theories, the Mercantilist view of international trade; the Classical trade theory based on absolute and comparative advantages; the Heckscher-Ohlin (H-O) Model; and the new trade theories including intra-industry/product differentiation, technological gap (Posner), product life cycle, global strategic rivalry, national competitive advantage (Porter) and country similarity (Linder's Hypothesis) trade theories are worth mentioning (Mikić, 1998, Salvatore, 2004).

The gravity model for trade known since the seminal work of Tinbergen (1962) has been frequently and successfully used for nearly sixty years for further understanding of the determinants of bilateral trade flows across countries and, subsequently, to analyze commercial policy measures. The model is analogous to the Newtonian physics function that describes the force of gravity. The standard gravity model proposed by Tinbergen (1962) to analyze the international trade flows between countries is formulated as:

$$
T_{i j}=G \frac{M_{i}^{\alpha} M_{j}^{\beta}}{D_{i j}^{\gamma}}
$$


Where $T_{i j}$ is the volume of trade between two countries ' $\mathrm{i}$ ' and ' $\mathrm{j}$ ' measured in monetary value, $M_{i(j)}$ represents relevant economic size of country ' $\mathrm{i}(\mathrm{j})$ ' and $D_{i j}$ is distance between the countries (usually measured between center to center). Customizing this standard model form to fit into data and modern trade theories has been the culture of empirical applications and so is this study's.

The early criticism against gravity model were mainly related to the model's nature of being a purely an econometric tool without a theoretical basis. However, finding a particular theoretical model that best describes the empirical findings of the gravity model is a matter of contention which also not the intention of this study. Besides, prominent theories of international trade (Deardorff, 1998, Frankel et al., 1997, Krugman, 1985, are worth mentioning) have found the model to be consistent with theories of trade based upon models of imperfect competition and with the Heckscher - Ohlin model.

The gravity model enjoyed an empirical success over time and many authors refer to this model as the "workhorse" of empirical trade studies (Eichengreen and Irwin, 1998, Westerlund and Wilhelmsson, 2011). It is also quoted as one of the most empirically successful approaches in international economics, both to explain the state of trade flows and estimate trade potentials (Thapa et al., 2012).

Different numerical techniques (both indexes and models) can be used to assess the level of bilateral trade potential between trading partner counters (Bano et al., 2013). In this regard, Revealed Comparative Advantage $(\mathrm{RCA})^{4}$ and Trade Conformity (TC) ${ }^{5}$ indexes developed by Balassa (1965) and Nam (2004b) respectively are widely utilized in the area. However, RCA and TC indexes are not free from criticism as they are mainly useful for a specific export item of a country which makes them highly data intensive and it is not to the best interest of this study. Furthermore, these index based measures do not enable researchers to quantify the amount of trade potential among nations as they only provide the insights and hence the $2^{\text {nd }}$ best alternative approach is employed in this study. The approach which is more applicable to empirical studies (see Batra (2006), Jakab et al. (2001a) and Thapa et al. (2012) for more details) relies on looking at the difference between the empirically predicted trade values of our model and actual trade values.

\subsection{Empirical Literature}

As far as understanding the determinants of Ethiopia's aggregate agricultural export to its trading partners and measuring the existing trade potential is concerned, the empirical works are limited to rely on. A critical review of the previous consulted empirical literature illustrates the existing knowledge gap in the area.

First and foremost, the previous studies have been inconclusive on the impact of the variables identified as key determinants to export especially the effect of population vary in sign, magnitude and significance level from one study to another. The effect of population has been found to be negligible as it was revealed by Kristjánsdóttir (2005) and Saray (2017) while it shows a positive significant effect of population on trade or export flows

\footnotetext{
${ }^{4}$ Revealed Comparative Advantage (RCA) indicates whether a country is in the process of extending the products in which it has a trade potential and it is computed as follows: $R C A_{i j}=\frac{\left(X_{i j} / X_{i t}\right)}{\left(X_{w j} / X_{w t}\right)}$. Where $X_{i j}$ and $X_{w j}$ are the value of country 'i' and world exports of product ' $\mathrm{j}$ ' respectively, and $X_{i t}$ and $X_{w t}$ refers to country i's and world's total exports (Balassa, 1965).

${ }^{5}$ Trade Conformity (TC) index is measured by share of each commodity from the aggregate export or import of the countries under consideration using the formula, $I T_{j k}=\frac{\sum_{i=1}^{n}\left(X_{i j} * M_{i k}\right)}{\sqrt{\sum_{i=1}^{n} X_{i j}^{2} * \sum_{i=1}^{n} M_{i k}^{2}}}$. Where $X_{i j}$ and $M_{i k}$ respectively denotes the share of commodity 'i' in country j's aggregate exports and country k's imports, $\sum_{i=1}^{n}$ refers to the sum of all the $n$ commodities $i=1,2,3, \ldots, n$ (Nam, 2004b).
} 
of countries as it was revealed by Johnston et al. (2014), Sejdini (2014) and Bussière and Schnatz (2009) findings. Population of home country has also been affecting Egyptians agricultural export negatively. The effect of importing countries population as well shows a negative effect as it was indicated by Gebrehiwot and Gebru (2015). By the same talking, the effect of regional trading agreements seems not to matter in some cases like Antonucci and Manzocchi (2005) while it affects trade flows positively as (see Batra (2006), Bussière and Schnatz (2009), Simwaka (2006) and Sejdini (2014)). Apart from this, the previous studies failed to incorporate the effect of some important variables like Contact-Intensive Money (CIM) which would serve as a proxy for financial or institutional development in the country (Thuresson, 2008) where as, this study has taken in to account of that factor.

Secondly, unlike to the previous studies, this study is intended to take the aggregate agricultural export of Ethiopia rather than focusing only on total trade flows or total exports or only few items. More specifically, they do not take all the agricultural export items into consideration while they attempt to figure out the export potential of some selected agricultural items like coffee and oil-seeds. Finally, by combining the theoretical insights with the empirical evidence of the literature sources we have gone through, we have noticed that the previous studies suffer from model mis-specification where studies like Allaro (2012), Demissie (2014) and Hussien (2015) who have made emphasis to some selected agricultural export items mainly coffee and oil-seeds have used modeling approaches different from gravity model. In this regard, the Vector Autoregressive (VAR) and Error Correction Model (ECM) approaches used by the aforementioned authors failed to enjoy the best qualities of a panel data analysis while the gravity model takes advantage of those qualities.

Studies that utilized the gravity model as well suffers from problems of mis-specification. In this regard, applications that employed cross-sectional data are the most affected (Egger, 2000) since cross-sections consider only a point in time. Among such studies Batra (2006) and Simwaka (2006) are the major ones. Other studies that employed panel data like Bekele (2011), Kassa (2013) and Tedla (2011) can also suffer from the crisis of mis-specification as they mainly focus on static nature of the model, which ignores the role for dynamic effects in trade (Bun and Klaassen, 2002).

Besides, the emphasis for most of the studies undertaken in Ethiopia was about analyzing the determinants of exports in general. None of the studies have tried to evaluate the case with a particular emphasis to agricultural export items though developing countries in general and Ethiopia in particular exports mainly agricultural primary products. They were also focused on the static nature of bilateral trade flows. The empirical findings, however, indicates that the flow of trade between nations is usually persistent (Anderson and van Wincoop, 2001, Egger, 2000, Harris and Mátyás, 1998). This implies that countries with a history of trading with one another, whether for affiliations related to politics, policies or other factors, generally continue doing so (Mussa et al., 1998). On the top of this, firms from exporting countries usually develop distribution channels which causes costs to be sunk and customers of the trading pairs being accustomed with each other's products which contributes for trade persistence that justifies our approach to use dynamic gravity model. Hence, this study diverges from the prevision empirical contribution in the sense that export from the agricultural sector only is duly analyzed taking into account the importance of the dynamic nature of international trade. 


\section{Methodology}

\subsection{Model Specification}

With the aim to achieve the objective of the study and in search of better results, this study has employed an augmented dynamic gravity model approach based on a panel data of 38 trading partner countries ${ }^{6}$ to Ethiopia sample countries.

The simplest form of the standard gravity model appears in the following form:

$$
T_{i j}=\beta_{0} \frac{Y_{i}^{\beta_{1}} Y_{j}^{\beta_{2}}}{D_{i j}^{\beta_{3}}}
$$

where $T_{i j}$ is the bilateral trade flows between country $i$ and $j, Y_{i(j)}$ represents economic size (GDP or GNP) of country $i$ and $j, D_{i j}$ represents distance between country $i$ and $j, \beta_{0}$ is the constant proportionality and $\beta_{1}, \beta_{2}$ and $\beta_{3}$ are parameters.

By taking natural logarithm (ln) of Equation 2, the augmented gravity model used in this study is consistent with the formulations used by Amstrong (2007), Antonucci and Manzocchi (2005), Batra (2006), Bekele (2011), Thuresson (2008) and Allaro (2012). In particular, the model is augmented by taking into account the effect of population size, trade freedom index and contract intensive money variables as follows:

$$
\begin{aligned}
\ln A E X P_{i j, t}= & \beta_{0}+\beta_{1} \ln A E X P_{i j, t-1}+\beta_{2} \ln P O P_{i, t}+\beta_{3} \ln P O P_{j, t}+\beta_{4} \ln T F I_{i, t} \\
& +\beta_{5} \ln T F I_{j, t}+\beta_{6} \ln C I M_{i, t}+\beta_{7} \ln C I M_{j, t}+\beta_{8} \ln D_{i j, t}+\varepsilon_{i j, t}
\end{aligned}
$$

where $\beta_{0 \ldots .8}$ are parameters to be estimated, $A E X P_{i j, t}$ and $A E X P_{i j, t-1}$ respectively represents agricultural export of Ethiopia at time $t$ and $t-1, P O P_{i(j)}{ }^{7}, T F I_{i(j)}{ }^{8}$ and $C I M_{i(j)}{ }^{9}$ respectively denotes population size, trade freedom index and contract intensive money of Ethiopia and its trading partners. $D_{i j, t}{ }^{10}$ represents distance between the capital city of Ethiopia, Addis Ababa, and its importing country $j$ and $\varepsilon_{i j, t}$ refers to the composite error term which constitutes a country pair individual effect $\left(\mu_{i t}\right)$ and idiosyncratic error term $\left(\nu_{i t}\right)$.

\footnotetext{
${ }^{6}$ Countries are selected based on their strong trade relationship with Ethiopia in terms of absorbing Ethiopia's agricultural export items. On aggregate, the 38 countries take around 89 percent share of Ethiopia's agricultural export items over the study period (ERCA, 2016). A few other countries are not included due to data incompleteness for variables of interest.

${ }^{7}$ POP represents both the production capacity and import demands of both exporting and importing countries and the signs of $\beta_{2}$ and $\beta_{3}$ is inconclusive based on previous findings.

${ }^{8}$ TFI that ranges from 0 to 100 is a proxy to country's trade policy and is calculated by Heritage Foundation taking both tariff and non-tariff barriers into consideration and hence positive coefficient is expected.

${ }^{9}$ CIM serves as a proxy to financial sector development and is defined as the ratio of non-currency money to total money supply $\left(C I M=\frac{\left(M_{2}-C\right)}{M_{2}}\right)$ where $C$ and $M_{2}$ respectively represents currency and broad money (Clague and Olson, 1999). The value of CIM ranges from 0 to 1 and the coefficient for the exporting country is expected to be negative while we presume a positive sign to the importing countries as many of the countries taken under consideration are in a better financial development status and high level of contract enforcement compared to Ethiopia which encourages more trade for the importing countries.

${ }^{10} \mathbf{D}$ is expected to have a negative sign as the physical distance between countries is expected to increase the trade costs which are modeled as "iceberg" costs. However, defining distance is problematic as it is time invariant which would not be a problem for cross sectional analysis unlike to panel data cases where time dimension is introduced in the analysis (Allaro, 2012, Saray, 2017). Thus, the weighted definition of distance $\left(W D_{i j}\right)$ is considered which is defined as $W D_{i j}=\frac{D_{i j} * G D P_{i t}}{\sum G D P_{i t}}$ where $G D P_{i t}$ represents GDP of the exporting country (Ethiopia) at time $\mathrm{t}$ and $\sum G D P_{i t}$ is the sum of all GDPs of Ethiopia over the study period.
} 


\subsection{Nature and Sources of Data}

Taking the period 1995 as a reference where a significant trade liberalization had been implemented in the country, the values of bilateral exports of Ethiopia for cereals and crops, coffee, tea, chat, oil-seeds, pulses, livestock products, fruits and vegetables and flowers to all the 38 countries over the study period (1995-2015) are taken into consideration.

Trade Statistics (DOTS) of IMF have been the major source for aggregate exports of Ethiopia to the importing countries. The corresponding values of agricultural export products on the other hand have been obtained from Ethiopian Revenue and Customs Authority's Trade Statistics. Data on GDP and Population size were collected from World Development Indicators of the World Bank and World Economic Outlook databases respectively. Contract intensive money data has been accessed from IMF's International Finance Statistics and Country's Central Banks while data on trade freedom index was obtained from the Index of Economic Freedom of the Heritage Foundation. Finally, data on distance (in kilometers) between Addis Ababa (capital city of Ethiopia, country ' $i$ ') and other capital cities of country ' $\mathrm{j}$ ' (as the crow flies or direct by air) were collected from Indonesian and Great Circle Mapper Websites, (www.indo.com/distance and www.gcmap.com/dist).

\subsection{Estimation Procedures}

Pooled OLS, fixed effect and random effect estimators are biased and inconsistent with the presence of a lagged dependent variable as an explanatory variable (like the case in our dynamic gravity model) and autocorrelation in the error terms, measurement error in the regressors, and simultaneity or endogeneity of regressors (Verbeek, 2004). Though there is, unfortunately, no perfect solution to this problem, the Generalized Method of Moments (GMM) estimation approach developed by Arellano and Bond (1991) provides the most efficient estimator based on the moment condition that the error term $\left(U_{i t}\right)$ and the instrument variables $\left(Z_{i t}\right)$ are uncorrelated.

The general framework for an individual-specific effect panel data dynamic model is expressed as an autoregressive model of order 1 (AR(1)) as suggested by Egger (2000) and Bun and Klaassen (2002). Arellano and Bond (1991) suggested a two-step procedure based on differencing and instrumenting where the first lag of the dependent variable is used as an instrument variable. Accordingly, the estimated gravity equation expressed at levels ( Equation 3) can be written in first differenced form as follows:

$$
\begin{array}{r}
\Delta \ln A E X P_{i j, t}=\beta_{0}+\beta_{1} \Delta \ln A E X P_{i j, t-1}+\beta_{2} \Delta \ln P O P_{i, t}+\beta_{3} \Delta \ln P O P_{j, t} \\
+\beta_{4} \Delta \ln T F I_{i, t}+\beta_{5} \Delta \ln T F I_{j, t}+\beta_{6} \Delta \ln C I M_{i, t} \\
+\beta_{7} \Delta \ln C I M_{j, t}+\beta_{8} \Delta \ln D_{i j, t}+\Delta \varepsilon_{i j, t}
\end{array}
$$

Equation 4 is then estimated and used for predicting the agricultural export potential of Ethiopia using the coefficients obtained from the latest version of system GMM estimation with the help of Stata 15 computer software package.

\subsubsection{Econometric Tests}

Our dynamic gravity model requires that the error term $\left(\varepsilon_{i j, t}\right)$ to be serially uncorrelated which implies that $\Delta \varepsilon_{i j, t}$ are uncorrelated with $\Delta \varepsilon_{i j, t-1}$ as the $\operatorname{Cov}\left(\Delta \varepsilon_{i j, t}, \Delta \varepsilon_{i j, t-1}\right)=$ $\operatorname{Cov}\left(\varepsilon_{i j, t}-\varepsilon_{i j, t-1}, \varepsilon_{i j, t-1}-\varepsilon_{i j, t-2}\right)=-\operatorname{Cov}\left(\varepsilon_{i j, t}, \varepsilon_{i j, t-2}\right) \neq 0$. As a result, $\Delta \varepsilon_{i j, t}$ will not 
be correlated with $\Delta \varepsilon_{i j, t-k}$ for all $k \geq 2$. In this regard, our test for serial autocorrelation that $\Delta \varepsilon_{i j, t}$ is correlated or uncorrelated with $\Delta \varepsilon_{i j, t-k}$ for all $k \geq 2$ has been carried using Arellano-Bond serial autocorrelation test where the result shows the presence of no serial correlation after the first difference as desired by the model.

Under GMM estimation, if there are ' $\mathrm{s}$ ' instruments and only ' $\mathrm{m}$ ' parameters to estimate, then panel GMM estimations leaves ( $\mathrm{s}-\mathrm{m}$ ) overidentifying restrictions. The extended version of the system GMM estimators developed by Roodman (2009) is used which enables us to perform the Sargan (1958) test of overidentifying restrictions when robust standard errors are specified. The result indicates that overidentifying conditions or instruments used in our model are valid. Further diagnosis tests revealed that there is first order autocorrelation in the disturbances which is expected due to the lagged dependent term in the dynamic model. However, the the absence of the second-order serial correlation in disturbances is not rejected as it is required.

Simple correlation using Klein's rule of thumb has been applied to test multicollinearity in our model and the result indicates that multicollinearity is not a problem in our specification of the dynamic gravity model. In this regard, through cross validation, those variables with a possibility to have series multicollinearity problem with population especially GDP per capita and GDP of countries were taken out of the model and there were no significant changes in coefficients as well as signs of the explanatory variables included in our model.

\section{Empirical Results and Discussion}

\subsection{Estimation Result}

The estimated results using system GMM indicates that many of the variables were significant and consistent with both theory and previous findings which confirms robustness of GMM compared to Pooled OLS, random effect and fixed effect models.

The lagged agricultural export, economic size measures (Population), trade freedom index, contract intensive money and distance variables were statistically significant in determining the agricultural export trend of Ethiopia. The effect of importing countries trade freedom index and contract intensive money indexes were found to be statistically insignificant.

The positive coefficient of the lagged agricultural export validates the dynamic nature of our gravity model over static models as it is also theoretically appealing that previously established trade relationship is expected to pave the way for exports to a particular destination in the subsequent years. Thus, according to the result, a one-percent increase or decrease in previous year's agricultural export boosts or lessens the current agricultural export by 0.59 percent, ceteris paribus.

Agricultural export of Ethiopia is also found to be more elastic to the changes in population of the exporting countries as its positive coefficient (3.46) indicates that a 1 percent increase or decrease in Ethiopia's population will lead to a more than proportionate (3.46) increase or decrease in its agricultural export value, ceteris paribus. This indicates that, the economies of scale outweigh the absorption effect which seems realistic as the large mass population of the country is engaged in agricultural activities. The statistically significant negative coefficient (0.47) of importing countries population on the other hand is consistent with the findings of Gebrehiwot and Gebru (2015) which confirms that absorption effect exceeding the economies of scale effect. This is statistically appealing as many of the countries taken into consideration are known to be producers of manufactured products and they 
Table 1: Arellano-Bond Dynamic Panel Data Estimation Result

\begin{tabular}{|l|c|c|c|}
\hline \multicolumn{4}{|c|}{ Dependent Variable: Log of Agricultural Export to trading partners $\left(\ln A E X P_{i j}\right)$} \\
\hline Explanatory Variables & Coefficient & z-ratio & p-value \\
\hline Lagged $\ln A E X P_{i j}$ & $0.591^{* * *}(0.295)$ & 20.04 & 0.000 \\
\hline $\ln P O P_{i}$ & $3.457^{* * *}(0.712)$ & 4.86 & 0.000 \\
\hline $\ln P O P_{j}$ & $-0.469^{* * *}(0.093)$ & -5.02 & 0.000 \\
\hline $\ln T F I_{i}$ & $0.742^{* * *}(0.162)$ & 4.58 & 0.000 \\
\hline $\ln T F I_{j}$ & $-0.125(0.207)$ & -0.60 & 0.547 \\
\hline $\ln C I M_{i}$ & $-4.094^{* * *}(0.832)$ & -4.92 & 0.000 \\
\hline $\ln C I M_{j}$ & $-0.046(0.242)$ & -0.19 & 0.849 \\
\hline $\ln D_{i j}$ & $-0.246^{* *}(0.115)$ & -2.14 & 0.033 \\
\hline Constant & $-50.548^{* * *}(12.334)$ & -4.10 & 0.000 \\
\hline $\begin{array}{l}\text { Sargan test of } \\
\text { overidentifying } \\
\text { restrictions }\end{array}$ & $\mathrm{Chi}^{2}(208)=33.6956$ & Prob $>\mathrm{Chi}^{2}=0.3701$ \\
\hline $\begin{array}{c}\text { Arellano-Bond test } \\
\text { for }\end{array}$ & \multicolumn{3}{|c|}{$\mathrm{AR}(1): \mathrm{Z}=-3.443$} \\
$\begin{array}{l}\text { Autocorrelation } \\
\mathrm{AR}(2): \mathrm{Z}=-0.877\end{array}$ \\
\hline No. of Observation & $38 \mathrm{Countries} \mathrm{X} 21$ Years $=798 \mathrm{Z}=0.0006$ \\
\hline
\end{tabular}

Note: Standard errors in parentheses, whereas, ${ }^{* * *}$ and ${ }^{* *}$ represents significance at $1 \%$ and $5 \%$ level of significance respectively, z-statistic and p-values are reported. The Models are estimated with the two-step GMM. For the diagnostic tests: Arellano-Bond test for serial correlation and the Sargan test of the validity of overidentification restrictions are employed. The null hypothesis of the Sargan test is $H_{0}$ : overidentifying restrictions are valid. The null hypothesis of the Arellano-Bond test for serial correlation is $H_{0}$ : no autocorrelation.

produce less of agricultural products and even the produced agricultural products are usually processed to manufactured ones rather than being exported as a primary agricultural product.

A statistically significant positive coefficient of exporting country's trade freedom index as well shows how a 1 percent improvement in trade freedom in Ethiopia encourages agricultural export by 0.74 percent as expected, ceteris paribus.

The other important variable found to be significant in having a negative impact on Ethiopia's agricultural export is the contract intensive money variable. The estimation result is in line with our priori expectation reflecting that a 1 percent increase in contract intensive money of the exporting country reduces agricultural export of the country by 4.09 percent, ceteris paribus. The concept behind arises from the very fact that higher contract intensive money implies less cash or currency to be circulated in the hands of the community engaged in agricultural production sector and agents/commercial traders involved in assembling of those items for export. Cash or currency plays a significant role in facilitating transactions for those economies with a limited financial access to the citizens where the situation is more important in the rural parts of Ethiopia (Diao and Pratt, 2010, Gebreselassie and Bekele, 2012, Urgessa, 2015). Therefore, the negative effect of exporting country's CIM is not a surprise as the lesser cash or currency in the hands of the people (liquidity problem) slows 
the speed of producing and assembling agricultural products for export.

Finally, the effect of distance has been consistent with our priori expectation and literature as its negative coefficient implies that distance, as a proxy for costs of international trade, has an adverse effect towards Ethiopia's agricultural export. More specifically, other things being constant, agricultural export flow of Ethiopia declines by 0.25 percent as the relative distance with the trading partners increases by 1 percent.

\subsection{Ethiopia's Agricultural Export Potential}

The gravity model is not only useful to identify the major determinants of Ethiopia's agricultural export, but is can also be utilized to predict the future export potential of the country. Thus, the estimated coefficients of the dynamic gravity model are employed for predicting Ethiopia's agricultural export potential. The estimated model result of Equation 4 as given below is used for the purpose.

$$
\begin{aligned}
\ln A E X P_{i j, t}= & -50.548+0.591 \ln A E X P_{i j, t-1}+3.457 \ln P O P_{i, t} \\
& -0.469 \ln P O P_{j, t}+0.742 \ln T F I_{i, t}-0.125 \ln T F I_{j, t} \\
& -4.094 \ln C I M_{i, t}-0.046 \ln C I M_{j, t}-0.246 \ln D_{i j, t}
\end{aligned}
$$

Two parameter references are used to predict the agricultural export trade potential of Ethiopia as used by Batra (2006), Gebrehiwot and Gebru (2015), Kaur and Nanda (2011), Rahman (2010) and Jakab et al. (2001b). The first parameter utilizes ratio indicators of potential and actual exports i.e., $\frac{P A E}{A A E}$ to analyze the future agricultural export direction of Ethiopia. A greater than unity ratio indicates that, there is a future potential expansion of agricultural export of Ethiopia with the respective destination.

The second parameter as well is based on the difference between potential and actual agricultural export (PAE-AAE) for each trading partner where a positive difference illustrates existence of unexploited agricultural export potential. For both cases, logarithmic values are converted to USD units using $e^{\text {lnaexp } i j t}$. Based on the values of the difference and ratio using the average of potential and actual export trades over the study period, all the 38 trading partner countries are placed under two categories, those with which potential for agricultural export is untapped (see Table 2) and those with Ethiopia's agricultural export exceeds its potential (see Table 3 ).

Table 2 reports that Ethiopia has a huge agricultural export potential with Djibouti (USD 202.67 million), Israel (USD 16.25 million), United Arab Emirates (USD 10.65 million), Singapore (USD 6.24 million), Yemen (USD 6.16 million), Switzerland (USD 6.12) not to forget existence of similar untapped export potential in Greece, Norway, Finland, Sweden, Romania, Kenya, Austria, Taiwan, Malesia, South Africa, Thailand and Australia over the period 1995-2015. Ratio of potential agricultural export to actual agricultural export indicates that, through appropriate export promotion policy, Ethiopia has a potential to expand its agricultural export earning with a more than double by exporting to Djibouti, Singapore, Switzerland, Greece, Norway, Finland and Romania. It is also noted that, European countries are the major potential destination to Ethiopia's agricultural export. Moreover, it has been noticed that Ethiopia did not use distance or proximity opportunities to export more agricultural products towards Djibouti and Yemen.

Ethiopia's agricultural export for about 20 countries including the major economies of Russia, Canada, United States, Saudi Arabia, Germany, China, Spain, United Kingdom, Italy and Japan has surpassed its potential. But it does not necessarily mean that trade with these countries is less important rather it has to be interpreted in a way that further 
Table 2: Countries with a Future Potential to Ethiopia's Agricultural Export

\begin{tabular}{|c|c|c|c|c|c|}
\hline \multirow[t]{2}{*}{$\mathbf{S N}$} & \multirow[t]{2}{*}{$\begin{array}{c}\text { Trading Partner } \\
\text { Country }\end{array}$} & \multirow{2}{*}{$\begin{array}{c}\text { Potential } \\
\text { Agricultural } \\
\text { Export (PAE) } \\
\text { in Million USD }\end{array}$} & \multirow{2}{*}{$\begin{array}{c}\text { Actual } \\
\text { Agricultural } \\
\text { Export (AAE) } \\
\text { in Million USD }\end{array}$} & \multicolumn{2}{|c|}{$\begin{array}{l}\text { Potential } \\
\text { Indicators }\end{array}$} \\
\hline & & & & $\frac{P A E}{A A E}$ & $P A E-A A E$ \\
\hline 1. & Djibouti & 254.37 & 51.7 & 4.92 & 202.67 \\
\hline 2. & Israel & 43.3 & 27.05 & 1.6 & 16.25 \\
\hline 3. & UAE & 40.42 & 29.77 & 1.36 & 10.65 \\
\hline 4. & Singapore & 8.69 & 2.45 & 3.55 & 6.24 \\
\hline 5. & Yemen & 22.04 & 15.88 & 1.39 & 6.16 \\
\hline 6. & Switzerland & 11.34 & 5.22 & 2.17 & 6.12 \\
\hline 7. & Greece & 10.86 & 5.18 & 2.1 & 5.69 \\
\hline 8. & Norway & 7.88 & 2.25 & 3.5 & 5.62 \\
\hline 9. & Finland & 7.83 & 2.38 & 3.29 & 5.45 \\
\hline 10. & Sweden & 12.3 & 8.07 & 1.52 & 4.22 \\
\hline 11. & Romania & 3.73 & 1.61 & 2.31 & 2.12 \\
\hline 12. & Kenya & 5.99 & 3.88 & 1.54 & 2.11 \\
\hline 13. & Austria & 29.87 & 28.53 & 1.05 & 1.35 \\
\hline 14. & Taiwan & 2.25 & 1.15 & 1.95 & 1.1 \\
\hline 15. & Malesia & 2.88 & 2.01 & 1.43 & 0.87 \\
\hline 16. & South Africa & 3.62 & 3.24 & 1.12 & 0.38 \\
\hline 17. & Thailand & 1.72 & 1.61 & 1.07 & 0.12 \\
\hline 18. & Australia & 4.95 & 4.91 & 1.01 & 0.04 \\
\hline
\end{tabular}

Source: Actual Agricultural Export from ERCA (2016) Database while the rest is author's own computation.

expansion of agricultural export to the aforementioned trading partners is not a priority. Agricultural export potential to some African countries mainly Sudan and Egypt as well has been exhausted which seems reasonable since these African countries themselves are more of agricultural exporters and transportation cost is relatively small between Ethiopia and these countries. Therefore, Ethiopia do not need to invest resources to promote more agricultural export to trading partners listed under Table 3 rather more efforts has to be exerted to maintain the good trading relationship.

\section{Conclusion and policy Recommendation}

\subsection{Conclusion}

The international trade literature with a particular emphasis on application of gravity models had identified various determinant factors for bilateral trade between economies. The literature on developing countries in general and Ethiopia in particular, however, are mainly focused on aggregate export despite the fact that developing countries are mainly primary agricultural product exporters. Besides, the effect of some determinant variables like population is inconclusive as the effect differs both in magnitude, sign and significance which 
Table 3: Countries where Ethiopia's Agricultural Export Surpassed its Potential

\begin{tabular}{|c|c|c|c|c|c|}
\hline SN & $\begin{array}{c}\text { Trading Partner } \\
\text { Country }\end{array}$ & $\begin{array}{c}\text { Potential } \\
\text { Agricultural } \\
\text { Export (PAE) } \\
\text { in Million USD }\end{array}$ & $\begin{array}{c}\text { Actual } \\
\text { Agricultural } \\
\text { Export (AAE) } \\
\text { in Million USD }\end{array}$ & \multicolumn{2}{|c|}{$\begin{array}{c}\text { Potential } \\
\text { Indicators }\end{array}$} \\
\cline { 3 - 6 } & & 4.46 & 4.73 & 0.94 & -0.28 \\
2. & Spain & 4.78 & 5.28 & 0.91 & -0.5 \\
2. & Canada & 1.31 & 1.89 & 0.69 & -0.58 \\
3. & Poland & 2.25 & 4.28 & 0.53 & -2.03 \\
4. & Russia & 3.78 & 6.07 & 0.62 & -2.29 \\
5. & South Korea & 26.2 & 28.52 & 0.92 & -2.32 \\
6. & Belgium & 31.2 & 37.35 & 0.84 & -6.14 \\
7. & Sudan & 7.6 & 14.1 & 0.54 & -6.5 \\
8. & Turkey & 1.45 & 10.71 & 0.18 & -6.69 \\
9. & India & 3.83 & 16.15 & 0.36 & -6.88 \\
10. & Pakistan & 8.73 & 21.45 & 0.54 & -7.42 \\
11. & Egypt & 9.47 & 22.59 & 0.44 & -11.98 \\
12. & France & 3.91 & 0.4 & -21.5 \\
13. & United Kingdom & 14.21 & 62.63 & 0.51 & -30.78 \\
14. & Italy & 31.85 & 81.15 & 0.52 & -39 \\
15. & Netherlands & 42.15 & 51.02 & 0.12 & -44.66 \\
16. & Saudi Arabia & 6.37 & 69.4 & 0.18 & -44.95 \\
17. & USA & 9.71 & 124.89 & 0.06 & -65.09 \\
18. & Japan & 4.31 & & -100.73 \\
19. & China & 24.16 & & & \\
20. & Germany & & & & \\
\hline
\end{tabular}

Source: Actual Agricultural Export from ERCA (2016) Database while the rest is author's own computation.

makes the issue of explaining the major determinants of the agricultural exports of the country to be an empirical interest.

The empirical results of this study indicates that application of dynamic gravity models is likely to produce consistent results where the lagged agricultural export has a positive and statistically significant effect on current agricultural export flows. The magnitude of the dynamic component (0.59) shows that a one percent positive shock in previous year's agricultural export leads to a 0.59 percent increments in current year agricultural exports. The supply side factor as well i.e., Ethiopia's population is found to have positive and significant impact towards agricultural export of Ethiopia. Importing country's population on the other hand has been found to affect Ethiopia's agricultural export flow negatively due to absorption effect. The positive effect of Ethiopia's trade openness measure as well reminds us how reducing both qualitative and quantitative trade restrictions would encourage agricultural export of Ethiopia.

Another notable result from the dynamic specification is that development of financial sectors and institutional quality improvement of the economy without taking their accessibility to the large mass population engaged in agricultural activities in to consideration 
is not helping the agricultural sector products to be commercialized in the international market. This is because the higher contract intensive money (more money held in financial institutions and less cash or currency money in the hands of economic agents) is found to have significant negative impact on Ethiopia's agricultural export as it creates a liquidity problem in the sector.

Regarding export potential, European countries remained to be the dominant future potential destinations of Ethiopia's agricultural export. Specifically, agricultural export potential to countries including Israel, Switzerland, Greece, Norway, Finland, Sweden, Romania and Austria are not yet exploited implying that export promotion towards these economies has to be taken into consideration together with infrastructural development to reduce international trade costs.

\subsection{Policy Implication}

Based on the findings of the study, the following recommendations are forwarded. The agricultural sector of the economy has to be further strengthened through agricultural extension services and access to agricultural inputs as the sector is the major source of the country's export and the subsequent foreign exchange earnings. Policy makers as well needs to take advantage of the large population size to encourage foreign direct investment inflows in the sector. The tendency to rely on few price and income inelastic agricultural export items has to be changed and a step towards diversifying the export items especially from other sectors, mainly cheap labour intensive ones, as well has to be encouraged. More importantly, both horizontal and vertical export diversification to reduce the narrow dependency nature of the country's overall export has to be accompanied by infrastructural improvements to reduce transportation and transaction costs.

Regarding the impact of contract intensive money on agricultural export of Ethiopia, the negative association needs to be critically examined as holding more money under the financial institutions has a retarding effect on both production and transactions of agricultural products in rural areas. Specifically, the government has to look for possible ways of improving financial access to the large mass population engaged in agricultural production and transaction beyond the attempts to improve operations and trustworthiness of financial institutions in the country. This is because though exporting agricultural products comes at the end, these items has to be first produced at a farm level and commercialized to the international market by exporters which implies that reducing all the bottlenecks that could render production as well as transaction of agricultural products at an individual farm level could finally boost the export earning performance of the economy.

\section{Future Research Directions}

Ethiopia's agricultural export sector have been the major focus of this research. As a future research direction, the results of gravity model approach can also be replicated for other key sectors of the economy using other methodological approaches such as networking models. 


\section{References}

Allaro, H. B. (2012). Export Performance of Oilseeds and ITS Determinants in Ethiopia. American Journal of Economics, 1(1):1-14.

Amstrong, S. (2007). Crawford School of Economics and Government Measuring Trade and Trade Potential : a Survey. Asian Economic Papers, 368.

Anderson, J. and van Wincoop, E. (2001). Gravity with gravitas: a solution to the border puzzle. NBER working paper series, 3(No.8079):1-37.

Antonucci, D. and Manzocchi, S. (2005). Does Turkey Have a Special Trade Relation With the EU ? A Gravity Model Approach. Policy Studies, Luiss Lab on European Economics LLEE Working Document, (35):1-24.

Arellano, M. and Bond, S. (1991). Some Tests of Specification for Panel Data: Monte Carlo Evidence and an Application to Employment Equations. The Review of Economic Studies, $58(2): 277-297$.

Balassa, B. (1965). Trade liberalisation and "revealed" comparative advantage 1. The manchester school, 33(2):99-123.

Bano, S., Takahashi, Y., and Scrimgeour, F. (2013). Asean-new zealand trade relations and trade potential: Evidence and analysis. Journal of Economic Integration, pages 144-182.

Batra, A. (2006). India's global trade potential: The gravity model approach. Global Economic Review Working Paper, (151).

Bekele, K. (2011). Does Real Exchange Rate Matter for Ethiopia's Exports? A Grvity model analysis. Addis Ababa University.

Bun, M. J. G. and Klaassen, F. (2002). The Importance of Dynamics in Panel Gravity Models of Trade. Ssrn.

Bussière, M. and Schnatz, B. (2009). Evaluating china's integration in world trade with a gravity model based benchmark. Open Economies Review, 20(1):85-111.

Chandrasekaran, B., Annadurai, K., and Somasundaram, E. (2010). A textbook of agronomy. New Age International Limited.

Clague, Christopher, P. K. S. K. and Olson, M. (1999). Contract-intensive money: Contract enforcement, property rights, and economic performance. Journal of Economic Growth, $4(2): 185-211$.

Deardorff, A. (1998). Determinants of bilateral trade: does gravity work in a neoclassical world? In The regionalization of the world economy, pages 7-32. University of Chicago Press.

Demissie, W. M. (2014). Determinants of Export Performance in Ethiopia : Var Model Determinants of Export Performance in Ethiopia: Var Model Analysis. Journal of Research in Commerce and Managment, 2(5):94-109.

Diao, Xinshen, A. S. T. B. Y. and Pratt, A. N. (2010). Economic Importance of Agriculture for Sustainable Development and Poverty Reduction : The Case Study of Ethiopia . (In Global forum on agricultureI):29-30. 
Egger, P. (2000). A note on the proper econometric specification of the gravity equation. Economics Letters, 66(1):25-31.

Eichengreen, B. and Irwin, D. A. (1998). The role of history in bilateral trade flows. In The regionalization of the world economy, pages 33-62. University of Chicago Press.

ERCA (2014). Import - export trade statistics. Addis Ababa, Ethiopia.

ERCA (2015). Import - export trade statistics. Addis Ababa, Ethiopia.

ERCA (2016). Import - export trade statistics. Addis Ababa, Ethiopia.

Frankel, J. A., Stein, E., and Wei, S.-J. (1997). Regional trading blocs in the world economic system. Peterson Institute.

Gandolfo, G. (1998). International trade theory and policy. Springer Science \& Business Media.

Gebrehiwot, G. and Gebru, B. (2015). Ethiopia's foreign trade potential: inferences from a dynamic gravity approach. International Journal of Economics and Business Research, $9(4): 355$.

Gebreselassie, A. and Bekele, T. (2012). A Review of Ethiopian Agriculture : Roles , Policy and Small-scale Farming Systems. (Medic 1999):36-65.

Ghani, E. and O'Connell, S. D. (2014). Can service be a growth escalator in low-income countries? The World Bank.

Harris, M. N. and Mátyás, L. (1998). The econometrics of gravity models. Melbourne Institute Working Paper, 5/98(03):1-17.

Hatab, A. A., Romstad, E., and Huo, X. (2010). Determinants of Egyptian Agricultural Exports: A Gravity Model Approach. Modern Economy, 01(03):134-143.

Hussien, H. B. (2015). Determinants of Coffee Export Supply in Ethiopia : Error Correction Modeling Approach. Journal of Economics and Sustainable Development, 6(5):31-38.

Jakab, Z. M., Kovács, M. A., and Oszlay, A. (2001a). How far has trade integration advanced?: An analysis of the actual and potential trade of three central and eastern european countries. Journal of Comparative Economics, 29(2):276-292.

Jakab, Z. M., Kovács, M. A., and Oszlay, A. (2001b). How far has trade integration advanced?: An analysis of the actual and potential trade of three central and eastern european countries. Journal of Comparative Economics, 29(2):276 - 292.

Johnston, L. A., Morgan, S. L., and Wang, Y. (2014). The Gravity of China's African Export Promise. The World Economy, 6(1):913-934.

Kalirajan, K. (1999). Stochastic varying coefficients gravity model: an application in trade analysis. Journal of Applied Statistics, 26(2):185-193.

Kalirajan, K. and Findlay, C. (2005). Estimating potential trade using gravity models: A suggested methodology. Foundation for Advanced Studies on International Development, Tokyo. 
Kassa, A. (2013). Evaluation of Ethiopia's Bilateral and Potential Exports in the Middle East : A Gravity Model Approach. Journal of Emergin Trends in Educational Research and Policy Studies, 4(1):198-204.

Kaur, S. and Nanda, P. (2011). an Analysis of Actual and Potential Exports of Pakistan With Saarc Countries: a Panel Data Analysis. Pakistan Journal of Applied Economics, 21(1 and 2):69-91.

Koo, W. W. (2003). Determining Bilateral Trade Patterns Using a Dynamic Gravity Equation. Applied Economics, (525).

Kristjánsdóttir, H. (2005). A Gravity Model for Exports from Iceland. Centre for Applied Microeconometrics, Department of Economics, University of Copenhagen.

Krugman, P. R. (1985). Increasing returns and the theory of international trade. Technical report, National Bureau of Economic Research.

Mikić, M. (1998). Trade policy, transition and economic development. In International Trade, pages 413-438. Springer.

Mussa, M., Eichengreen, B., DelL'Ariccia, G., Detragiache, E., Milesi-Ferretti, G. M., and Tweedie, A. (1998). Capital Account Liberalization Theoretical and Practical Aspects, volume I.

Nam, S. (2004a). Trade Structure and Trade Potential between China, Japan and Korea. Korea Institute for International Economic Policy (KIEP) Working Paper Series, 40.

Nam, S.-y. (2004b). Trade structure and trade potential between china, japan and korea. Korea Institute for International Economic Policy (KIEP) Working Paper Series, 2004:40.

NBE (2015). Annual economic performance report. Addis Ababa, Ethiopia.

Rahman, M. M. (2010). Exploring Australia's global trade potential: a gravity approach with panel data 2. International Journal of Business Research, (44(1)):229-244.

Reis, J. and Forte, R. (2016). The impact of industry characteristics on firms' export intensity. International Area Studies Review, 19(3):266-281.

Roodman, D. (2009). How to do xtabond2: An introduction to difference and system gmm in stata. The Stata Journal, 9(1):86-136.

Salvatore, D. (2004). International economics, eight edition.

Saray, M. O. (2017). Trade Potential of Turkey with Asia-Pacific Countries : Evidence from Panel Gravity Model Trade Potential of Turkey with Asia-Pacific Countries : Evidence from Panel Gravity Model. International Economic Studies, 36(1):19-26.

Sargan, J. D. (1958). The estimation of economic relationships using instrumental variables. Econometrica, 26(3):393-415.

Sejdini, A. (2014). International Trade of Albania . Gravity model. European Journal of Social Science Education and Research, 2(1):220-228.

Simwaka, K. (2006). Dynamics of malawi's trade flows: a gravity model approach. Munich Personal RePEc Archive, (1122). 
Smith, V. H. (2014). The 2014 agricultural act: Us farm policy in the context of the 1994 marrakesh agreement and the doha round. note prepared for ICTSD, Geneva.

Sousa, C. M. (2004). Export performance measurement: an evaluation of the empirical research in the literature. Academy of marketing science review, 2004:1.

Tedla, M. (2011). Determinants of Trade in Services in Africa: A Gravity Model Approach. Shool of Graduate Studies, Addis Ababa University.

Thapa, S. B. (2012). Nepal's Trade Flows : Evidence from Gravity Model. NBR Economic Review, 24-1(17):1-12.

Thapa, S. B. et al. (2012). Nepal's trade flows: Evidence from gravity model. NRB Economic Review, 24(1):16-27.

Thuresson, C. (2008). Contract Inforcement and its Impact on Bilateral trade. Jonkoping International Business School.

Tinbergen, J. (1962). An analysis of world trade flows. Shaping the world economy, 3:1-117.

Udah, S., Nwachukwu, I., Nwosu, A., Mbanasor, J., and Akpan, S. (2015). Determinants of agricultural export growth in nigerian. International Journal of Agriculture, Forestry and Fisheries, 3(3):105.

UNDP (2015). Ethiopia's quarterly economic brief.

Urgessa, T. (2015). The determinants of agricultural productivity and rural household income in ethiopia. Ethiopian Journal of Economics, 24(2):63-91.

Verbeek, M. (2004). A Guide to Modern Econometrics(2rd edition). John Wiley and Sons.

WB (2015). World development indicator (wdi) database.

Westerlund, J. and Wilhelmsson, F. (2011). Estimating the gravity model without gravity using panel data. Applied Economics, 43(6):641-649. 


\section{Appendices}

\section{A List of Trade Partner Countries Considered for the Study}

\begin{tabular}{|l|l|l|l|l|l|}
\hline SN & Country & SN & Country & SN & Country \\
\hline 1. & Australia & 14. & Italy & 27. & South Korea \\
2. & Austria & 15. & Japan & 28. & Spain \\
3. & Belgium & 16. & Kenya & 29. & Sudan \\
4. & Canada & 17. & Malaysia & 30. & Sweden \\
5. & China & 18. & Netherlands & 31. & Switzerland \\
6. & Djibouti & 19. & Norway & 32. & Taiwan \\
7. & Egypt & 20. & Pakistan & 33. & Thailand \\
8. & Finland & 21. & Poland & 34. & Turkey \\
9. & France & 22. & Romania & 35. & UAE \\
10. & Germany & 23. & Russia & 36. & United Kingdom \\
11. & Greece & 24. & Saudi Arabia & 37. & USA \\
12. & India & 25. & Singapore & 38. & Yemen \\
13. & Israel & 26. & South Africa & & \\
\hline
\end{tabular}

